\title{
"Navigating Spaces: Moving Along the (Dis)enfranchisement Spectrum through a High School GSA"
}

\author{
Cailey Underhill ${ }^{1}$
}

This paper identifies the components needed for new organizations to create programs that support inclusivity and enfranchisement by working within pre-existing power structures. The researcher considers how to bring to bear the resources of those already in positions of power to provide a voice for those without a means of advocating for themselves. While this paper seeks to provide a model for success across multiple modalities, the research focuses on enfranchisement within educational contexts through the development of a high school GSA (Gay-Straight Alliance). Seen through this lens, the researcher has identified four key elements necessary for progress towards enfranchisement. [Article copies available for a fee from The Transformative Studies Institute. E-mail address: journal@transformativestudies.org

http://www.transformativestudies.org (C2017 by The Transformative Studies Institute. All rights reserved.]

KEYWORDS: Disenfranchisement, Inclusivity, High School GSA, LGBTQ+.

For Lesbian, Gay, Bisexual, Transgender, Queer/Questioning, and other individuals (LGBTQ+), many facets of society in the United States

\footnotetext{
${ }^{1}$ Cailey Underhill is a high school English teacher in the Canton Central School District in St. Lawrence County, NY. She teaches several grade levels at Hugh C. Williams Senior High School. She holds a Bachelor of Arts in English, with minors in history and psychology, from Cazenovia College, and a Master of Science Degree in English Education: Preparation Grades 7-12 from Syracuse University. In addition to teaching English, she has worked with administrators and a committed group of students to revive the GSA in the Hugh C. Williams Senior High School.

Acknowledgements: First, the author would like to thank the administrators in the Canton Central School District for their support in restarting the GSA and completing this article, and the GSA Advisory Board for their effort and advice. Second, thank you to the members of the Gender, Sex, and Sexuality Conference who supported the article and provided editorial contributions: Emily Hamilton-Honey, Jennifer Thomas, and Melissa Lee. Finally, the author would like to thank the GSA students who have made our organization possible.
} 